\title{
Epidemiological surveillance methods for vector-borne diseases
}

\author{
P.N. Thompson ${ }^{(1) *} \&$ E. Etter ${ }^{(1,2)}$ \\ (1) Department of Production Animal Studies, Faculty of Veterinary Science, University of Pretoria, Private Bag \\ X/04, Onderstepoort, 0110, South Africa \\ (2) UPR 22 AGIRs-Department ES, Centre de coopération International en Recherche Agronomique pour le \\ Développement (CIRAD), Montpellier, France \\ *Corresponding author: peter.thompson@up.ac.za
}

\section{Summary}

Compared with many other diseases, the ever-increasing threat of vectorborne diseases (VBDs) represents a great challenge to public and animal health managers. Complex life cycles, changing distribution ranges, a variety of potential vectors and hosts, and the possible role of reservoirs make surveillance for VBDs a grave concern in a changing environment with increasing economic constraints. Surveillance activities may have various specific objectives and may focus on clinical disease, pathogens, vectors, hosts and/or reservoirs, but ultimately such activities should improve our ability to predict, prevent and/or control the diseases concerned. This paper briefly reviews existing and newly developed tools for the surveillance of VBDs. A range of examples, by no means exhaustive, illustrates that VBD surveillance usually involves a combination of methods to achieve its aims, and is best accomplished when these techniques are adapted to the specific environment and constraints of the region. More so than any other diseases, VBDs respect no administrative boundaries; in addition, animal, human and commodity movements are increasing dramatically, with illegal or unknown movements difficult to quantify. Vector-borne disease surveillance therefore becomes a serious issue for local and national organisations and is being conducted more and more at the regional and international level through multidisciplinary networks. With economic and logistical constraints, tools for optimising and evaluating the performance of surveillance systems are essential and examples of recent developments in this area are included. The continuous development of mapping, analytical and modelling tools provides us with an enhanced ability to interpret, visualise and communicate surveillance results. This review also demonstrates the importance of the link between surveillance and research, with interactions and benefits in both directions.

\section{Keywords}

Epidemiology - Risk-based surveillance - Sentinel surveillance - Syndromic surveillance - Vector-borne disease.

\section{Introduction}

Recent decades have seen significant expansion of the ranges of several vector-borne diseases (VBDs), including African swine fever (ASF), Crimean-Congo haemorrhagic fever, bluetongue (BT), West Nile fever (WNF), Rift Valley fever (RVF) and Japanese encephalitis (JE), as well as the emergence of new vector-borne pathogens, such as Schmallenberg virus. The reasons for this may be manifold, including changing patterns of human and animal settlement, increased volumes of short- and longdistance human and animal movement, alteration of land use, and changing climatic and ecological conditions. This represents an important challenge for epidemiologists who must develop tools to better detect, monitor and even predict changes in the distribution of pathogens and their vectors in the future.

In endemic areas there is a dynamic balance between the pathogen, the vertebrate host population(s), the vector 
population composition and abundance, and the local environment. Many vector-borne pathogens can infect multiple host species, some of which may not be clinically affected by the infection and may be important as reservoir species, from which infection may be transmitted to a target population. One of the biggest limiting factors to our understanding of patterns of disease is, in many cases, a lack of detailed knowledge of vector ecology. Since vector distribution, movement and life cycles are influenced to a large extent by local and regional climatic factors, it stands to reason that climate and climate change have a large influence on patterns of VBD emergence $(1,2,3,4)$. Another important factor influencing vector dynamics, at least on a local scale, is human-induced alteration of the vectors' breeding habitat, and this has resulted in important changes in the distribution of several VBDs in recent decades $(3,5)$. Biodiversity loss also tends to be associated with increased pathogen transmission and incidence of disease (6); this has been demonstrated both for WNF (7) and for Lyme disease (8). An analysis of over 300 emerging disease events since 1940 shows that hotspots for emerging VBDs are more likely to occur in tropical, developing countries, whereas surveillance and scientific efforts are concentrated in other areas (9). There is therefore a need for more VBD surveillance in those regions most likely to give rise to new diseases.

As a result of the existence of multiple life-cycle stages and hosts, most VBDs have a complex epidemiology, many with irregular patterns of emergence and spread that have proven difficult to predict and often to explain. Surveillance for VBDs is therefore often conducted at various levels and may be directed at the host species, the vectors, or both. Surveillance may be directed at the pathogen itself, either indirectly (serological) or directly (agent isolation or detection), to demonstrate the presence of the pathogen, or it may be aimed at detecting the vector or accurately defining its distribution, as an important step in assessing and mapping the risk of disease transmission. Methods for vector surveillance are discussed in more detail elsewhere in this issue.

Surveillance may be defined as 'the systematic, continuous or repeated, measurement, collection, collation, analysis, interpretation and timely dissemination of animal health and welfare related data from defined populations... to describe health hazard occurrence and to contribute to the planning, implementation, and evaluation of risk mitigation actions' (10). Standardisation of the numerous and often confusing terminologies applied to animal health surveillance activities has recently been attempted (11), and the reader is referred to these publications $(10,11)$ for detailed definitions of the various types and components of surveillance systems. There are many forms of surveillance, and the design of the most appropriate system will depend on its precise purpose and the type(s) of diseases or healthrelated events to be targeted.

\section{Purpose of vector-borne disease surveillance}

Surveillance may be general, in order to detect a variety of known or unknown diseases in a population, or hazardspecific, aimed at detecting one or more specific known diseases (11), e.g. sentinel surveillance systems to detect seroconversion to defined pathogens (12). Surveillance information is intended for use in outbreak management, to inform disease control measures, to inform trade policy, and to prioritise further surveillance and control measures (11). A surveillance system may consist of a number of components or surveillance activities. The specific purpose of the surveillance system as a whole, and of each activity, should be carefully considered and expressly stated. The aims of surveillance for VBDs may include one or more of the following:

- the early detection of outbreaks of VBD

- the detection of cases so that control measures can be implemented

- the detection of vector-borne pathogens in reservoirs and/or vectors

- substantiating freedom from disease or infection

- describing the distribution and level of disease or pathogen circulation

- monitoring space-time trends in levels of disease or pathogen circulation

- monitoring production or health indicators

- determining the geographic distribution of known or potential vector populations

- mapping transmission risk

- identifying novel pathogens that may result in new emerging diseases in the future.

In addition, surveillance activities may also contribute to improving our knowledge of the disease and help to inform and refine further surveillance by:

- identifying risk factors and determinants of pathogen occurrence and transmission

- generating hypotheses regarding potential pathogen reservoirs or vectors

- assessing the animal and public health importance of a VBD

- identifying risk factors for the emergence of a VBD in non-endemic areas. 
Depending on the objectives of a surveillance programme, data may be collected about one or more of the following parameters:

- seroprevalence in host population(s), including seasonal and annual changes

- seroprevalence in known or putative reservoir species, including seasonal and annual changes

- infection prevalence (pathogen isolation or detection) in vectors or hosts

- species composition, abundance and temporal/spatial variation in vector populations

- species composition, abundance and temporal/spatial variation in host and reservoir populations

- the incidence of clinical disease, mortality or other health-related outcomes in host populations

- the presence and level of potential risk factors for disease, related to the agent, host, vector or environment.

\section{Early warning surveillance}

Early warning surveillance, sometimes termed scanning surveillance, refers to the surveillance of health indicators, e.g. mortalities or laboratory submissions, to increase the likelihood of detecting new or unexpected disease threats in a timely manner (11). This is an important component of surveillance for VBDs and is widely used, since it potentially allows for the detection of multiple known and unknown emerging diseases. Early warning surveillance often forms part of comprehensive early warning contingency plans that also include many other components $(13,14)$. In passive surveillance, the reporting of the information is initiated by the observer. This reporting may be improved (enhanced passive surveillance) by the investigator standardising the way in which information is submitted, or by encouraging producers or the public to submit samples or report diseases. Examples of this are tick reporting in Great Britain (15), and the use of hunter-killed white-tailed deer (Odocoileus virginianus) in Canada for tick and tickborne pathogen surveillance (16). Passive surveillance for wild bird mortality and human disease was an important component, along with sentinel and vector surveillance, of ArboNET, which was developed in 2000 in response to the emergence of West Nile virus (WNV) in the United States in 1999, and later expanded to include several other arboviruses of public health importance (17). The sensitivity of the various passive surveillance components for WNV, as well as sentinel surveillance (see below), in terms of time until the detection of an outbreak, is shown in Fig. 1. There may be several opportunities to detect VBDs in hosts and vectors; however, selecting the most sensitive

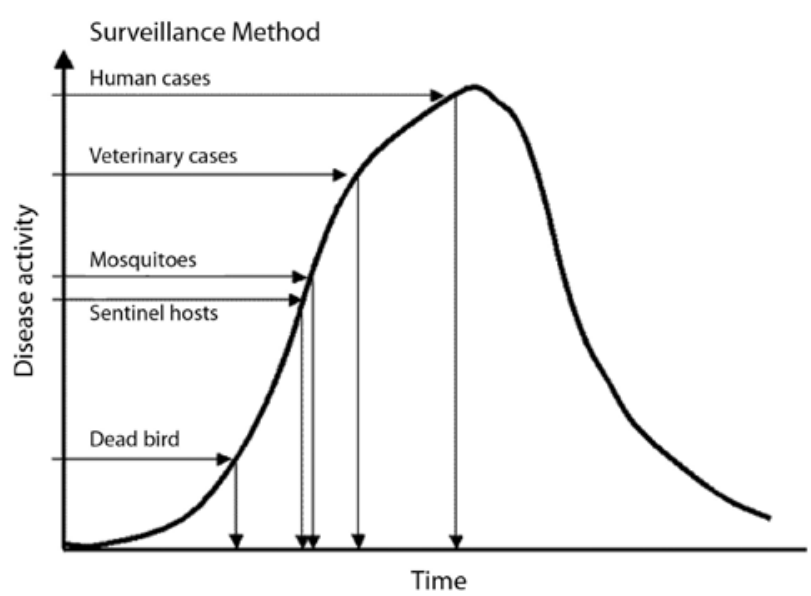

Fig. 1

Estimated sensitivity of surveillance for West Nile virus activity, using different passive and sentinel surveillance methods (18)

and cost-effective methods will depend on the disease and the specific environment.

\section{Sentinel surveillance}

Sentinel surveillance employs repeated sampling from subjects at selected sites, which act as proxies for the entire population (11). The sites may be randomly selected, or located in areas where the probability of disease detection is increased, i.e. risk-based sampling (see below). In the Australian National Arbovirus Monitoring Programme, cattle are sampled and insects are trapped at key locations around Australia, and the sites are selected on the basis of perceived risk of disease introduction and the willingness of producers to participate (19). To detect recent seroconversion, young animals, free of maternal antibodies, are sampled at weekly to monthly intervals during the summer. In North America, chicken flocks are used as sentinels for WNV and eastern equine encephalitis virus activity (20). In Greece, it was shown that serological surveillance using domestic pigeons as sentinels could act as an early warning system for WNV outbreaks in humans (21). Sentinel surveillance can also be deployed at a regional scale as demonstrated in West Africa for RVF, where a network of sentinel small ruminant herds was located in potential high-risk areas for RVF in Mauritania, Senegal and Mali (22).

\section{Syndromic surveillance}

Syndromic surveillance makes use of pre-diagnosis data, targeting general groups of diseases or syndromes; it thereby reduces the time lag associated with passive surveillance by aiming to detect disease before laboratory confirmation (23). It is thus generally more sensitive and timely than 
passive surveillance, but may suffer from a low specificity. However, various aberration detection algorithms can be used to achieve the desired balance between the ability of the system to detect disease when it is present and its ability to avoid false alarms (23).

An inventory of syndromic surveillance initiatives in Europe has recently been published (24). May et al. (25) give examples of syndromic surveillance for several human VBDs. Elbers et al. (26) describe the early detection of the first BT virus 8- (BTV-8-) infected sheep flocks in the Netherlands by farmers and veterinary practitioners on the basis of an unusual clinical syndrome. Another use of syndromic surveillance is the potential for the notification of abortions in livestock to provide early warning of RVF (27). The use of a continuous indicator (milk yield) for early detection of VBDs, using a scan statistic to detect clusters of low milk production, has been evaluated and the main limitation was found to be its low specificity (28). Nevertheless, such methods using routinely collected data are likely to provide a powerful means of early detection of disease outbreaks in the future. The combination of syndromic surveillance with the identification of priority areas for emergency vector control has been proposed in the public health field for an early response to dengue outbreaks (29), and should also be explored for veterinary VBDs.

In the case of zoonotic diseases, one aim of VBD surveillance in endemic areas may be to assess the public health significance of the disease(s) in the area concerned. In many tropical regions malaria is responsible for a high proportion of febrile disease cases; however, this may also result in the misdiagnosis of other infections with similar presenting symptoms, including VBDs such as dengue, JE or chikungunya fever, with consequent ignorance or underestimation of their importance (30). An efficient method of surveillance to investigate such zoonotic diseases could be achieved by single or, preferably, paired serological testing of febrile patients presenting at clinics for arboviruses $(31,32,33)$.

\section{Risk-based surveillance}

Risk-based surveillance aims to increase the efficiency and benefit-cost ratio of surveillance by employing risk assessment methods to prioritise surveillance requirements in either the sampling or analysis of the surveillance data (34). Risk-based sampling methods are built into most surveillance systems for VBDs, particularly those aimed at the early detection of disease, since preferentially sampling those strata of the population, or certain geographic areas, considered to be at the greatest risk of disease occurrence increases the likelihood of early detection, and improves the cost-effectiveness of the system (35). The risk assessment may be based on expert opinion, the presence of known risk factors, and/or the outputs of qualitative or quantitative risk analyses. One example of a quantitative risk analysis that could be used to inform risk-based surveillance is an assessment of the risk of transporting WNV-infected mosquitoes on transatlantic flights (36). Because of the important influence of climatic factors, there is usually a cyclical seasonal nature to the levels of circulation between vectors and hosts, and this should be taken into account in the design of a surveillance programme. Sampling at certain times of the year, during high-risk periods, is another application of risk-based sampling (19).

Social network analysis (SNA) has been used since the 1930s in sociology and psychology to describe the behaviour of individuals within a group, of the group itself and of the whole system (network), and has been used in epidemiology since the 1990s (37). Martínez-López et al. (38) reviewed the use of SNA in veterinary epidemiology and indicated that it could be a valuable tool for risk-based animal disease surveillance, by identifying components of the network that are more important for disease transmission. A study by Frössling et al. (39) included SNA approaches to improve a risk-based surveillance system by selecting relevant animal movements for risk-based sampling. This significantly increased the sensitivity of the surveillance, when compared to completely random sampling. The application to VBDs may be more restricted, due to the greater complexity of the networks (40). Nevertheless, future developments of this method to optimise risk-based VBD surveillance should be explored.

\section{Participatory surveillance}

Another area of surveillance now receiving more attention is participatory surveillance, using participatory rural appraisal methods. This aims to enhance surveillance sensitivity via an inclusive approach, using key informants to tap into local knowledge and traditional information networks ( 11 , 41). Through increasing the role of local stakeholders by actively involving them in the surveillance system, this may improve our understanding of the socio-economic context of the disease, and enhance the efficiency of surveillance and the acceptability of control measures. Examples of studies of VBDs with participatory surveillance components include a study of Chagas disease in Peru (42) and one of theileriosis in Kenya (43). A retrospective study of RVF in Kenya (44) used participatory methods to understand previous outbreaks in order to organise future surveillance and response plans. These methods not only considered clinical disease but also assessed vector identification and population changes, as well as weather conditions and their association with and timing relative to clinical disease. It 
was concluded that the use of active syndromic surveillance by including livestock owners' observations could lead to the earlier detection of RVF outbreaks.

\section{Mapping and spatial analysis in vector-borne disease surveillance}

Advances in mapping and geographic information system (GIS) technologies have made it easier to rapidly communicate surveillance data in various visual formats to aid understanding and facilitate decision-making, and have also allowed more complex spatial and spatiotemporal analyses to identify risk factors for, and even predict, VBD occurrence. Identifying high-risk areas is one of the important outputs of a surveillance programme that can then be fed into the planning and implementation of prevention and control measures, as well as used to refine further risk-based surveillance activities.

Information on vector distribution can be compiled into risk maps, indicating potential high-risk areas for disease (45, 46). These risk maps can be further refined by incorporating data on other known risk factors, as well as previous disease outbreak data. A spatial risk model is a GIS-based statistical model used to estimate vector presence or abundance, or VBD presence or incidence, in a particular geographic area, with the outputs generally displayed in map format, as a risk surface (47). Eisen and Eisen (47) give several examples of the use of spatial risk models, both to identify risk factors for vector and/or disease occurrence and to generate risk maps, which may be useful in predicting disease occurrence. Other examples of the use of GIS-based models include risk index models for predicting eastern equine encephalitis virus transmission to horses (48) and human WNV infection (49), generalised linear models using remotely sensed environmental variables to predict BTV seropositivity in cattle in northern Australia (50) and WNV vector abundance in Greater Toronto (51), and near real-time monitoring of sea surface temperatures and the normalised difference vegetation index (NDVI) to predict RVF outbreaks in Africa (52). Spatial analysis of syndromic surveillance data for acute encephalitis syndrome in Nepal was used to conclude that this approach could be useful to provide an early warning signal for JE surveillance (53). When there is little confidence in the data on the absence of a disease or vector, ecological niche modelling can be used with presence-only data to map risk areas for vector or disease occurrence. This has been used for several VBDs, such as plague in California ground squirrels (54), RVF vectors in Saudi Arabia (55), vectors and reservoirs of leishmaniosis in North America (56) and WNV vectors in Iowa (57).
Whatever the purpose of spatial or spatio-temporal modelling of VBDs, it is important that the collected data are of high quality and of sufficient spatial and temporal resolution to enable meaningful analysis. Appropriate spatial and temporal units should be used to calculate and present VBD incidence, since too crude a scale of data collection or analysis may obscure fine-scale risk patterns $(58,59,60)$. Surveillance systems are increasingly linked to automated data analysis aimed at detecting unusual events and spatiotemporal clustering of events (space-time interaction), for rapid notification to decision-makers. A problem with such methods in many regions is a lack of knowledge of the underlying population at risk and therefore the specification of the baseline disease risk; developing methods to account for spatial heterogeneity in background rates, as well as for movements in the population at risk, is a continuing area of research (59).

For several diseases, it has been suggested that wind-blown insect vectors could have been responsible for the spread of the virus to previously unaffected areas (61), such as the entry of BT into Europe (62) and Australia (63) and of JE into Australia (64). Wind-spread models have been developed to model such dispersions and may be used to identify areas at risk of arboviral incursion due to windborne insects $(65,66,67)$. Some models have been validated using field data and have proved useful in explaining the origins of incursions $(67,68)$, demonstrating their potential value in informing surveillance programmes.

Indeed, one of the main aims of mapping and modelling is to inform surveillance and control activities. The outputs of such models should be clearly communicated to decisionmakers, along with an honest account of their inherent assumptions and limitations. A spatially explicit multicriteria decision analysis (MCDA) framework for VBDs has been proposed, which combines risk mapping with other spatially varying factors to facilitate informed and objective decision-making (69). A spatial MCDA approach was recently used to predict suitability for ASF endemicity in Africa, using habitat suitability for Ornithodoros spp. as one of the criteria (70).

\section{Evaluation of surveillance systems for vector-borne disease}

The development of new methods using up-to-date tools and scientific knowledge is crucial for VBD surveillance, particularly in a changing environment where human and animal population movements are increasing and issues such as climate change force decision-makers to rapidly 
adapt their management systems. Specific local conditions, rapid economic development and a plethora of management options in a financially restricted environment result in public and animal health managers facing situations where the wrong decisions could lead to hazardous consequences. This calls for methods to evaluate the efficiency and costeffectiveness of surveillance systems for the early detection and rapid control of diseases. Regular and objective assessment of surveillance is particularly important in situations where resources are limited.

Multi-criteria decision analysis algorithms can be used to rank and compare alternatives, based on multiple criteria that can be evaluated using quantitative or qualitative indicators (71). Generous et al. (72) proposed the use of MCDA to evaluate data streams in surveillance systems to determine which streams were the most useful; they concluded that the particular goals of the surveillance system (early warning, early detection, situational awareness or consequence management) were of crucial importance in the ranking of the data streams. Multi-criteria decision analysis was also used to prioritise infectious diseases associated with climate change in Canada, $50 \%$ of which were VBDs (2).

Surveillance systems generally suffer from under-detection issues, the extent of which is usually unknown. Capturerecapture methodology may be a useful tool for assessing reporting rates and case detection probabilities, provided that more than one data set of cases is available (73). By using two or more sources of information from the same population, and matching cases between sources, capturerecapture methods allow modelling of the number of cases not detected by any of the sources. It may therefore be a suitable tool for quantitative assessment of the sensitivity of a surveillance system.

A recent semi-quantitative method for surveillance evaluation proposed 78 assessment criteria, divided into ten sections, representing the functional parts of a surveillance system and including vector surveillance for VBDs (74). An adaptation of this tool, called SNATrop, was designed to assess national surveillance systems for animal diseases and zoonoses in developing countries (75), allowing assessment of the strengths and weaknesses of the systems and their overall cost.

The importance of considering economic criteria in animal health management has been recognised for some time, and should be used to inform the design of surveillance systems (76). The techniques most frequently used for an economic assessment of surveillance are optimisation models, and cost-benefit and cost-effectiveness analyses. Standardised methods to conduct cost-effectiveness and cost-utility analyses of surveillance programmes for VBDs are a useful tool for decision-makers, allowing comparisons between economic evaluation studies in different countries. To deal with the complexity of the impact of animal diseases on society, and given the dearth of good-quality data in some regions, participatory rapid appraisal based on stated preference methods can be introduced in order to obtain quantitative estimates both of the impact of a disease and of the impact and effectiveness of the associated surveillance system.

New tools combine epidemiology, sociology and economic approaches to perform socio-economic evaluations of surveillance systems $(77,78)$. Such tools should allow the extraction of additional value from surveillance in various socio-economic environments, and allow decision-makers to choose the best surveillance system to implement. A new tool for qualitative analysis, using a mathematical method known as 'loop analysis', has recently been tested for evaluating animal disease surveillance and control (79), and this could potentially be employed for VBD surveillance. Another innovative approach is the use of stochastic scenario tree modelling to assess the sensitivity of surveillance systems and of their individual components; this quantitative approach has been used to evaluate the sensitivity of BT surveillance in Switzerland (80).

\section{Surveillance and research}

The importance of ongoing epidemiological research on VBDs should not be underestimated. The results of such research serve to refine and improve surveillance efforts, e.g. by informing risk-based sampling. In turn, data from surveillance can feed into research activities, e.g. by helping to formulate further hypotheses to be tested.

An important question regarding many newly emerging or re-emerging VBDs concerns the existence and identity of possible reservoirs. Haydon et al. (81) defined a reservoir as: 'one or more epidemiologically connected populations or environments in which the pathogen can be permanently maintained and from which infection is transmitted to the defined target population'. Although some VBDs have welldefined reservoirs, in others, such as RVF, the existence and identity of reservoirs is still poorly understood. This may make it difficult to design effective surveillance programmes. In order to identify a reservoir of infection, one should first aim to identify natural infection in the putative reservoir population; secondly, one must show persistence of infection in the reservoir and, finally, one needs to demonstrate the transmission of the pathogen to the human or animal target population. Longitudinal studies would be required to demonstrate the persistence of infection in the reservoir (81). Demonstrating transmission to the target population may require laboratory experiments to obtain conclusive proof, but strong circumstantial evidence may be obtained 
by molecular typing or sequencing of the pathogens isolated from the putative reservoir and the target host and gathered during active surveillance.

Ongoing research into known and potential vector species is essential to ensure that surveillance activities are informed by the best possible knowledge. A case in point is the emergence of BT in Central Europe in 2006 in the absence of its known vectors, while in southern Europe, surveillance was focused on its known vector, Culicoides imicola (82, 83). Entomological and epidemiological research, risk assessment and risk-based surveillance should therefore all go hand in hand, to help in accounting for uncertainties about vector competence and the possibility of 'new' vectors emerging $(84,85,86)$.

Owing to the complexity of these diseases, research programmes on VBDs often involve a number of different disciplines, necessitating a high degree of interdisciplinary collaboration between veterinary field workers, microbiologists, entomologists, epidemiologists, modellers, meteorologists, bioinformaticians and others. An example of such a large research network is the EDENext project on the biology and control of vector-borne infections in Europe (87). In another, more narrowly focused research effort, the United States Armed Forces Health Surveillance Center, Division of Global Emerging Infections Surveillance and Response System Operations (AFHSC-GEIS), has developed the RVF prediction project (52) into a worldwide 'predictive surveillance' programme, aimed at the prediction and detection of emerging disease outbreaks, with a particular focus on VBDs such as RVF, JE, leishmaniosis and chikungunya fever (88). Since next-generation sequencing (NGS) technologies became available for metagenomic studies, their use in concert with traditional surveillance methods has allowed for the more rapid discovery and characterisation of new and potentially emerging pathogens from hosts, vectors and reservoirs (89). Arthropods are a particularly rich source of new viral pathogens, and new arthropod-borne viruses are increasingly being discovered and characterised using NGS (90).

One challenge encountered in the surveillance of VBDs is how to manage the data that accumulate. These data may take various forms, including serological, clinical, vector population, climatic, spatio-temporal and molecular data. There is, therefore, a need to carefully consider and plan a data management strategy and to develop data management systems which are capable of accommodating such information (91).

\section{Conclusion}

The rate of emergence, re-emergence and spread of VBDs is on the increase, and is likely to increase further in the future, making it essential that methods for VBD surveillance are continuously being developed and improved. Many alternative methods are available, including some that have not yet been applied to veterinary VBD surveillance. The increasing availability of high-resolution satellite data and advances in GIS technology allow for the development of more complex models for analysing surveillance data; yet it is important that these data are of high quality and relevant to the questions being addressed. Surveillance and research on VBDs is, by nature, interdisciplinary and so collaborative networks and systems must be developed to facilitate the planning and co-ordination of surveillance activities, the integration of surveillance and research, efficient data management and analysis, and the communication of outputs to decision-makers and other stakeholders. It is also crucial to increase surveillance activities in tropical regions where new VBDs are more likely to emerge.

\title{
Méthodes de surveillance épidémiologique des maladies à transmission vectorielle
}

\author{
P.N. Thompson \& E. Etter
}

\author{
Résumé \\ La menace toujours accrue que représentent les maladies à transmission \\ vectorielle par rapport à bien d'autres maladies est un véritable défi pour les \\ responsables de la santé publique et de la santé animale. En raison des cycles \\ évolutifs complexes, des changements de distribution, de la diversité des vecteurs \\ et des hôtes potentiels et de l'éventuelle interaction de réservoirs, la surveillance
}


des maladies à transmission vectorielle pose des problèmes de plus en plus préoccupants dans un environnement en pleine mutation soumis à des contraintes économiques croissantes. Les activités de surveillance peuvent avoir plusieurs finalités spécifiques, en ciblant une maladie clinique, des agents pathogènes, des vecteurs, des hôtes et/ou des réservoirs, mais dans tous les cas elles doivent améliorer notre capacité à prédire, à prévenir et/ou à contrôler les maladies surveillées. Les auteurs examinent brièvement les outils existants ainsi que les dernières innovations en matière de surveillance des maladies à transmission vectorielle. Une série non exhaustive d'exemples confirme que la surveillance de ces maladies recourt généralement à plusieurs méthodes combinées pour atteindre ses objectifs, et qu'elle a davantage de chances de réussir lorsque ces techniques sont adaptées à l'environnement spécifique et aux contraintes de la région. Plus que toute autre maladie, les maladies véhiculées par les vecteurs ignorent les frontières administratives ; en outre, nous assistons aujourd'hui à une augmentation spectaculaire des mouvements d'animaux, de personnes et de biens, y compris les mouvements illégaux ou non répertoriés, qui sont difficiles à quantifier. La surveillance des maladies à transmission vectorielle pose donc de sérieuses difficultés aux organisations locales et nationales, et c'est de plus en plus à l'échelle régionale et internationale qu'elle doit être entreprise, en mobilisant des réseaux pluridisciplinaires. Compte tenu des contraintes économiques et logistiques, il est essentiel de disposer d'outils permettant d'optimiser et d'évaluer les performances des systèmes de surveillance ; les auteurs fournissent quelques exemples récents de réussite dans ce domaine. Le développement continu des outils cartographiques, analytiques et de modélisation améliore nos capacités à interpréter, à visualiser et à diffuser les résultats de la surveillance. Les auteurs montrent également l'importance du lien qui doit exister entre la surveillance et la recherche, les interactions entre ces deux domaines leur étant mutuellement bénéfiques.

\title{
Mots-clés
}

Épidémiologie - Maladie à transmission vectorielle - Surveillance axée sur le risque Surveillance des animaux sentinelles - Surveillance syndromique.

\section{Métodos de vigilancia epidemiológica de las enfermedades transmitidas por vectores}

\author{
P.N. Thompson \& E. Etter
}

\section{Resumen}

En comparación con otros muchos tipos de afecciones, la creciente amenaza que suponen las enfermedades transmitidas por vectores plantea grandes dificultades a los responsables de salud pública y sanidad animal. Ciclos vitales complejos, áreas de distribución que se modifican, multiplicidad de posibles vectores y anfitriones y la eventual intervención de reservorios hacen de la vigilancia de las enfermedades transmitidas por vectores un grave problema, en 
un contexto lábil y sujeto a crecientes limitaciones económicas. Las actividades de vigilancia pueden perseguir diferentes objetivos específicos y estar centradas en la enfermedad clínica, los patógenos, los vectores, los anfitriones y/o los reservorios, pero en última instancia tales actividades deben dotarnos de una mayor capacidad de predecir, prevenir y/o controlar las enfermedades en cuestión. Los autores pasan brevemente revista a las herramientas existentes y de reciente aparición para vigilar las enfermedades transmitidas por vectores. Con una serie de ejemplos, desde luego no exhaustiva, ponen de relieve que para cumplir los objetivos de la vigilancia de dichas enfermedades se suele requerir una combinación de métodos, y que lo idóneo en tal labor es que esas técnicas estén adaptadas a las condiciones y limitaciones específicas de cada región. Más que cualquier otro tipo de enfermedades, las transmitidas por vectores no respetan frontera administrativa alguna. Además, los desplazamientos de animales, personas y mercancías se multiplican a gran velocidad, sin olvidar los movimientos ilegales o desconocidos, que son difíciles de cuantificar. La vigilancia de las enfermedades transmitidas por vectores constituye pues una labor de suma importancia para las organizaciones locales y nacionales, que cada vez más corre a cargo de redes multidisciplinares que trabajan a escala regional e internacional. Dadas las limitaciones económicas y logísticas, resulta esencial disponer de herramientas para optimizar y evaluar la eficacia de los sistemas de vigilancia, y los autores ofrecen ejemplos de avances recientes en la materia. La continua aparición de herramientas de cartografía, análisis y modelización mejora nuestra capacidad para interpretar, visualizar y comunicar los resultados de la vigilancia. Los autores también demuestran la importancia que revisten los vínculos entre vigilancia e investigación, con interacciones y beneficios que van en ambos sentidos.

\section{Palabras clave}

Enfermedad transmitida por vectores - Epidemiología - Vigilancia basada en el riesgo Vigilancia centinela - Vigilancia sindrómica.

\section{References}

1. Gould E.A. \& Higgs S. (2009). - Impact of climate change and other factors on emerging arbovirus diseases. Trans. Roy. Soc. Trop. Med. Hyg., 103 (2), 109-121. doi:10.1016/j. trstmh.2008.07.025

2. Cox R., Sanchez J. \& Revie C.W. (2013). - Multi-criteria decision analysis tools for prioritising emerging or re-emerging infectious diseases associated with climate change in Canada. PLoS ONE, 8 (8), e68338.

3. Gratz N.G. (1999). - Emerging and resurging vector-borne diseases. Annu. Rev. Entomol., 44 (1), 51.

4. De la Roque S., Rioux J.A. \& Slingenbergh J. (2008). - Climate change: effects on animal disease systems and implications for surveillance and control. In Climate change: impact on the epidemiology and control of animal diseases (S. de La Rocque, S. Morand \& G. Hendrickx, eds). Rev. Sci. Tech. Off. Int. Epiz., 27 (2), 339-354.
5. Chevalier V., de La Rocque S., Baldet T., Vial L. \& Roger F. (2004). - Epidemiological processes involved in the emergence of vector-borne diseases: West Nile fever, Rift Valley fever, Japanese encephalitis and Crimean-Congo haemorrhagic fever. In Emerging zoonoses and pathogens of public health concern (L.J. King, ed.). Rev. Sci. Tech. Off. Int. Epiz., 23 (2), 535-555.

6. Keesing F., Belden L.K., Daszak P., Dobson A., Harvell C.D., Holt R.D., Hudson P., Jolles A., Jones K.E., Mitchell C.E., Myers S.S., Bogich T. \& Ostfeld R.S. (2010). - Impacts of biodiversity on the emergence and transmission of infectious diseases. Nature, 468 (7324), 647-652.

7. Swaddle J.P. \& Calos S.E. (2008). - Increased avian diversity is associated with lower incidence of human West Nile infection: observation of the dilution effect. PLoS ONE, 3 (6), e2488. 
8. Keesing F., Brunner J., Duerr S., Killilea M., Logiudice K., Schmidt K., Vuong H. \& Ostfeld R.S. (2009). - Hosts as ecological traps for the vector of Lyme disease. Proc. Roy. Soc. Biol. Sci., 276 (1675), 3911-3919.

9. Jones K.E., Patel N.G., Levy M.A., Storeygard A., Balk D., Gittleman J.L. \& Daszak P. (2008). - Global trends in emerging infectious diseases. Nature, 451 (7181), 990-993.

10. Hoinville L.J. (2013). - Animal health surveillance terminology: final report from pre-ICAHS [International Conference on Animal Health Surveillance] workshop, July 2013 (version 1.2). Available at: www.fp7-risksur.eu/sites/ fp7-risksur.eu/files/partner_logos/icahs-workshop-2011_ surveillance_tewrminology_report_V1.2.pdf (accessed on 18 January 2015.)

11. Hoinville L.J., Alban L., Drewe J.A., Gibbens J.C., Gustafson L., Häsler B., Saegerman C., Salman M. \& Stärk K.D.C. (2013). - Proposed terms and concepts for describing and evaluating animal-health surveillance systems. Prev. Vet. Med., 112 (1-2), 1-12.

12. Racloz V., Griot C. \& Stärk K.D.C. (2006). - Sentinel surveillance systems with special focus on vector-borne diseases. Anim. Hlth Res. Rev., 7 (1/2), 71-79.

13. Geering W.A., Roeder P.L. \& Obi T.U. (1999). - Manual on the preparation of national animal disease emergency preparedness plans. Food and Agriculture Organization of the United Nations (FAO), Rome.

14. Centers for Disease Control and Prevention (CDC) (2013). West Nile virus in the United States: guidelines for surveillance, prevention, and control. United States Department of Health and Human Services, Fort Collins, Colorado, 69 pp. Available at: http://www.cdc.gov/westnile/resources/pdfs/ wnvGuidelines.pdf (accessed on 18 January 2015).

15. Jameson L.J. \& Medlock J.M. (2011). - Tick surveillance in Great Britain. Vector-borne Zoonotic Dis., 11 (4), 403-412.

16. Bouchard C., Leighton P.A., Beauchamp G., Nguon S., Trudel L., Milord F., Lindsay L.R., Bélanger D. \& Ogden N.H. (2013). - Harvested white-tailed deer as sentinel hosts for early establishing Ixodes scapularis populations and risk from vector-borne zoonoses in southeastern Canada. J. Med. Entomol., 50 (2), 384-393.

17. Lindsey N.P., Brown J.A., Kightlinger L., Rosenberg L. \& Fischer M. (2012). - State Health Department perceived utility of and satisfaction with ArboNET, the US National Arboviral Surveillance System. Public Hlth Rep., 127 (4), 383-390.

18. Lemon S.M., Hamburg M.A., Sparling P.F, Choffnes E.R. \& Mack A. (2007). - Global infectious disease surveillance and detection: assessing the challenges - finding solutions: workshop summary. Forum on Microbial Threats. National Academies Press, Washington, DC, 284 pp.

19. Kirkland P.D. (2004). - Bluetongue viruses, vectors and surveillance in Australia: the current situation and unique features. Vet. Ital., 40 (3), 47-50.
20. Loftin K.C., Diallo A.A., Herbert M.W., Phaltankar P.G., Yuan C., Grefe N., Flemming A., Foley K., Williams J., Fisher S.L., Elberfeld M., Constantine J., Burcham M., Stallings V. \& Xia D. (2006). - Five-year surveillance of West Nile and eastern equine encephalitis viruses in southeastern Virginia. J. Environ. Hlth, 68 (9), 33-40.

21. Chaintoutis S.C., Dovas C.I., Papanastassopoulou M., Gewehr S., Danis K., Beck C., Lecollinet S., Antalis V., Kalaitzopoulou S., Panagiotopoulos T., Mourelatos S., Zientara S. \& Papadopoulos O. (2014). - Evaluation of a West Nile virus surveillance and early warning system in Greece, based on domestic pigeons. Comp. Immunol. Microbiol. Infect. Dis., 37 (2), 131-141.

22. Food and Agriculture Organization of the United Nations (FAO) (2000). - Implementation of a Rift Valley fever surveillance system in Mali, Mauritania and Senegal. EMPRES Transbound. Anim. Dis. Bull., 13. Available at: www.fao.org/3/ax734le/X7341e03.htm (accessed on 2 October 2014).

23. Dórea F.C., Sanchez J. \& Revie C.W. (2011). - Veterinary syndromic surveillance: current initiatives and potential for development. Prev. Vet. Med., 101 (1-2), 1-17.

24. Dupuy C., Bronner A., Watson E., Wuyckhuise-Sjouke L., Reist M., Fouillet A., Calavas D., Hendrikx P. \& Perrin J.-B. (2013). - Inventory of veterinary syndromic surveillance initiatives in Europe (Triple-S project): current situation and perspectives. Prev. Vet. Med., 111 (3-4), 220-229.

25. May L., Chretien J.-P. \& Pavlin J. (2009). - Beyond traditional surveillance: applying syndromic surveillance to developing settings - opportunities and challenges. BMC Public Hlth, 9 (1), 242.

26. Elbers A.R.W., Backx A., Meroc E., Gerbier G., Staubach C., Hendrickx G., van der Spek A. \& Mintiens K. (2008). - Field observations during the bluetongue serotype 8 epidemic in 2006: I. Detection of first outbreaks and clinical signs in sheep and cattle in Belgium, France and the Netherlands. Prev. Vet. Med., 87 (1-2), 21-30.

27. Bronner A., Hénaux V., Vergne T., Vinard J.L., Morignat E., Hendrikx P., Calavas D. \& Gay E. (2013). - Assessing the mandatory bovine abortion notification system in France using unilist capture-recapture approach. PLoS ONE, 8 (5), e63246. doi:10.1371/journal.pone.0063246.

28. Madouasse A., Marceau A., Lehebel A., BrouwerMiddelesch H., van Schaik G., Van der Stede Y. \& Fourichon C. (2013). - Evaluation of a continuous indicator for syndromic surveillance through simulation. Application to vector borne disease emergence detection in cattle using milk yield. PLoS ONE, 8 (9), e 73726. doi:0.1371/journal.pone.0073726.

29. Lemon S.M., Sparling P.F., Hamburg M.A., Relman D.A., Choffnes E.R. \& Mack A. (2008). - Vector-borne diseases: understanding the environmental, human health, and ecological connections, workshop summary. National Academy of Sciences, Washington, DC, 40 pp. 
30. Acestor N., Cooksey R., Newton P.N., Ménard D., Guerin P.J., Nakagawa J., Christophel E., González I.J. \& Bell D. (2012). - Mapping the aetiology of non-malarial febrile illness in Southeast Asia through a systematic review - Terra incognita impairing treatment policies. PLoS ONE, 7 (9), e44269.

31. Bonney J.H.K., Osei-Kwasi M., Adiku T.K., Barnor J.S., Amesiya R., Kubio C., Ahadzie L., Ölschläger S., Lelke M., Becker-Ziaja B., Pahlmann M. \& Gunther S. (2013). Hospital-based surveillance for viral hemorrhagic fevers and hepatitides in Ghana. PLoS Negl. Trop. Dis., 7 (9), 1.

32. Forshey B.M., Guevara C., Laguna-Torres V.A., Cespedes M., Vargas J., Gianella A., Vallejo E., Madrid C., Aguayo N., Gotuzzo E., Suarez V., Morales A.M., Beingolea L., Reyes N., Perez J., Negrete M., Rocha C., Morrison A.C., Russell K.L., Blair P.J., Olson J.G. \& Kochel T.J. (2010). - Arboviral etiologies of acute febrile illnesses in western South America, 2000-2007. PLoS Negl. Trop. Dis., 4 (8), e787.

33. McGready R., Ashley E.A., Wuthiekanun V., Tan S.O., Pimanpanarak M., Viladpai-nguen S.J., Jesadapanpong W., Blacksell S.D., Peacock S.J., Paris D.H., Day N.P., Singhasivanon P., White N.J. \& Nosten F. (2010). - Arthropod borne disease: the leading cause of fever in pregnancy on the Thai-Burmese border. PLoS Negl. Trop. Dis., 4 (11), e888. doi:10.1371/journal.pntd.0000888.

34. Stärk K., Regula G., Hernandez J., Knopf L., Fuchs K., Morris R. \& Davies P. (2006). - Concepts for risk-based surveillance in the field of veterinary medicine and veterinary public health: review of current approaches. BMC Hlth Serv. Res., 6 (1), 20.

35. Reist M., Jemmi T. \& Stärk K.D.C. (2012). - Policy-driven development of cost-effective, risk-based surveillance strategies. Prev. Vet. Med., 105 (3), 176-184.

36. Brown E.B.E., Adkin A., Fooks A.R., Stephenson B., Medlock J.M. \& Snary E.L. (2012). - Assessing the risks of West Nile virus-infected mosquitoes from transatlantic aircraft: implications for disease emergence in the United Kingdom. Vector-borne Zoonotic Dis., 12 (4), 310-320.

37. Rothenberg R.B., Potterat J.J. \& Woodhouse D.E. (1996). Personal risk taking and the spread of disease: beyond core groups. J. Infect. Dis., 174 (Suppl. 2), S144-S149.

38. Martínez-López B., Perez A.M. \& Sánchez-Vizcaíno J.M. (2009). - Social network analysis. Review of general concepts and use in preventive veterinary medicine. Transbound. Emerg. Dis., 56 (4), 109-120.

39. Frössling J., Ohlson A., Björkman C., Håkansson N. \& Nöremark M. (2012). - Application of network analysis parameters in risk-based surveillance: examples based on cattle trade data and bovine infections in Sweden. Prev. Vet. Med., 105 (3), 202-208.
40. Bisanzio D., Bertolotti L., Tomassone L., Amore G., Ragagli C., Mannelli A., Giacobini M. \& Provero P. (2010). - Modeling the spread of vector-borne diseases on bipartite networks. PLoS ONE, 5 (11), e13796.

41. Mariner J.C., Hendrickx S., Pfeiffer D.U., Costard S., Knopf L., Okuthe S., Chibeu D., Parmley J., Musenero M., Pisang C., Zingeser J., Jones B.A., Ali S.N., Bett B., McLaws M., Unger F., Araba A., Mehta P. \& Jost C.C. (2011). - Integration of participatory approaches into surveillance systems. Rev. Sci. Tech. Off. Int. Epiz., 30 (3), 653-659.

42. Bayer A.M., Hunter G.C., Gilman R.H., Cornejo del Carpio J.G., Naquira C., Bern C. \& Levy M.Z. (2009). - Chagas disease, migration and community settlement patterns in Arequipa, Peru. PLoS Negl. Trop. Dis., 3 (12), e567.

43. Moenga B.O., Muchemi G.M., Kang'ethe E.K., Kimenju J.W., Mutiga E.R. \& Matete G.O. (2013). - The impact of climate change on the incidence of cattle diseases in a pastoral area of Kenya. Livest. Res. Rural Dev., 25 (4), Article 67.

44. Jost C.C., Nzietchueng S., Kihu S., Bett B., Njogu G., Swai E.S. \& Mariner J.C. (2010). - Epidemiological assessment of the Rift Valley fever outbreak in Kenya and Tanzania in 2006 and 2007. Am. J. Trop. Med. Hyg., 83 (Suppl. 2), 65-72.

45. Ogden N.H., St-Onge L., Barker I.K., Brazeau S., Bigras-Poulin M., Charron D.F., Francis C.M., Heagy A., Lindsay L.R., Maarouf A., Michel P., Milord F, O'Callaghan C.J., Trudel L. \& Thompson R.A. (2008). - Risk maps for range expansion of the Lyme disease vector, Ixodes scapularis, in Canada now and with climate change. Int. J. Hlth Geogr., 7, 24. doi:10.1186/1476-072X-7-24.

46. Caligiuri V., Giuliano G.A., Vitale V., Chiavacci L., Travaglio S., Manelli L., Piscedda S., Giardina M. \& Mainolfi R. (2004). Bluetongue surveillance in the Campania region of Italy using a geographic information system to create risk maps. Vet. Ital., 40 (3), 385-389.

47. Eisen L. \& Eisen R.J. (2011). - Using geographic information systems and decision support systems for the prediction, prevention, and control of vector-borne diseases. Annu. Rev. Entomol., 56 (1), 41-61.

48. Van der Kelen P., Downs J.A., Unnasch T. \& Stark L. (2014). A risk index model for predicting eastern equine encephalitis virus transmission to horses in Florida. Appl. Geogr., $48,79-86$.

49. Kilpatrick A.M. \& Pape W.J. (2013). - Predicting human West Nile virus infections with mosquito surveillance data. Am. J. Epidemiol., 178 (5), 829-835.

50. Klingseisen B., Stevenson M. \& Corner R. (2013). - Prediction of bluetongue virus seropositivity on pastoral properties in northern Australia using remotely sensed bioclimatic variables. Prev. Vet. Med., 110 (2), 159-168. 
51. Yoo E.H. (2014). - Site-specific prediction of West Nile virus mosquito abundance in Greater Toronto Area using generalized linear mixed models. Int. J. Geogr. Inf. Sci., 28 (2), 296-313.

52. Anyamba A., Linthicum K.J., Small J., Britch S.C., Pak E., de La Rocque S., Formenty P., Hightower A.W., Breiman R.F., Chretien J.P., Tucker C.J., Schnabel D., Sang R., Haagsma K., Latham M., Lewandowski H.B., Magdi S.O., Mohamed M.A., Nguku P.M., Reynes J.M. \& Swanepoel R. (2010). - Prediction, assessment of the Rift Valley fever activity in East and Southern Africa 2006-2008 and possible vector control strategies. Am. J. Trop. Med. Hyg., 83 (2, Suppl.), 43-51. doi: 10.4269/ajtmh.2010.09-0289.

53. Robertson C., Pant D.K., Joshi D.D., Minu S., Meena D. \& Stephen C. (2013). - Comparative spatial dynamics of Japanese encephalitis and acute encephalitis syndrome in Nepal. PLoS ONE, 8 (7), e66168.

54. Holt A.C., Salkeld D.J., Fritz C.L., Tucker J.R. \& Gong P. (2009). - Spatial analysis of plague in California: niche modeling predictions of the current distribution and potential response to climate change. Int. J. Hlth Geogr., 8, 38. doi:10.1186/1476-072X-8-38.

55. Sallam M.F., Al-Ahmed A.M., Abdel-Dayem M.S. \& Abdullah M.A.R. (2013). - Ecological niche modeling and land cover risk areas for Rift Valley fever vector, Culex tritaeniorhynchus Giles in Jazan, Saudi Arabia. PLoS ONE, 8 (6), e65786. doi:10.1371/journal.pone.0065786.

56. Gonzalez C., Wang O., Strutz S.E., Gonzalez-Salazar C., Sanchez-Cordero V. \& Sarkar S. (2010). - Climate change and risk of leishmaniasis in North America: predictions from ecological niche models of vector and reservoir species. PLoS Negl. Trop. Dis., 4 (1), e585.

57. Larson S.R., DeGroote J.P., Bartholomay L.C. \& Sugumaran R. (2010). - Ecological niche modeling of potential West Nile virus vector mosquito species in Iowa. J. Insect Sci., 10,110 .

58. Eisen L. \& Eisen R.J. (2007). - Need for improved methods to collect and present spatial epidemiologic data for vectorborne diseases. Emerg. Infect. Dis., 13 (12), 1816-1820.

59. Robertson C., Nelson T.A., MacNab Y.C. \& Lawson A.B. (2010). - Review of methods for space-time disease surveillance. Spatial Spatio-temp. Epidemiol., 1 (2-3), 105-116.

60. Liu H. \& Weng Q.H. (2012). - Enhancing temporal resolution of satellite imagery for public health studies: a case study of West Nile virus outbreak in Los Angeles in 2007. Remote Sensing Environ., 117, 57-71.

61. Sellers R.F. (1980). - Weather, host and vector: their interplay in the spread of insect-borne animal virus diseases. J. Hyg. (London), 85 (1), 65-102.

62. Hendrickx G., Gilbert M., Staubach C., Elbers A., Mintiens K., Gerbier G. \& Ducheyne E. (2008). - A wind density model to quantify the airborne spread of Culicoides species during north-western Europe bluetongue epidemic, 2006. Prev. Vet. Med., 87 (1-2), 162-181. doi:10.1016/j.prevetmed. 2008.06.009.
63. Eagles D., Deveson T., Walker P.J., Zalucki M.P. \& Durr P. (2012). - Evaluation of long-distance dispersal of Culicoides midges into northern Australia using a migration model. Med. Vet. Entomol., 26 (3), 334-340.

64. Ritchie S.A. \& Rochester W. (2001). - Wind-blown mosquitoes and introduction of Japanese encephalitis into Australia. Emerg. Infect. Dis., 7 (5), 900-903.

65. Eagles D., Walker P.J., Zalucki M.P. \& Durr P.A. (2013). Modelling spatio-temporal patterns of long-distance Culicoides dispersal into northern Australia. Prev. Vet. Med., 110 (3-4), 312-322

66. Ducheyne E., Lange M., Van der Stede Y., Meroc E., Durand B. \& Hendrickx G. (2011). - A stochastic predictive model for the natural spread of bluetongue. Prev. Vet. Med., 99 (1), 48-59.

67. Burgin L.E., Gloster J., Sanders C., Mellor P.S., Gubbins S. \& Carpenter S. (2013). - Investigating incursions of bluetongue virus using a model of long-distance Culicoides biting midge dispersal. Transbound. Emerg. Dis., 60 (3), 263-272.

68. Eagles D., Melville L., Weir R., Davis S., Bellis G., Zalucki M., Walker P. \& Durr P. (2014). - Long-distance aerial dispersal modelling of Culicoides biting midges: case studies of incursions into Australia. BMC Vet. Res., 10 (1), 135.

69. Hongoh V., Hoen A.G., Aenishaenslin C., Waaub J.-P., Belanger D. \& Michel P. (2011). - Spatially explicit multicriteria decision analysis for managing vector-borne diseases. Int. J. Hlth Geogr., 10 (1), 70.

70. De Glanville W., Vial L., Costard S., Wieland B. \& Pfeiffer D. (2014). - Spatial multi-criteria decision analysis to predict suitability for African swine fever endemicity in Africa. BMC Vet. Res., 10 (1), 9.

71. Aenishaenslin C., Hongoh V., Cisse H., Hoen A., Samoura K., Michel P., Waaub J.-P. \& Belanger D. (2013). - Multi-criteria decision analysis as an innovative approach to managing zoonoses: results from a study on Lyme disease in Canada. BMC Public Hlth, 13 (1), 897.

72. Generous N., Margevicius K.J., Taylor-McCabe K.J., Brown M., Daniel W.B., Castro L., Hengartner A. \& Deshpande A. (2014). - Selecting essential information for biosurveillance: a multicriteria decision analysis. PLoS ONE, 9 (1), e86601.

73. Vergne T., Grosbois V., Durand B., Roger F. \& Dufour B. (2012). - Using capture-recapture approaches for assessing livestock disease surveillance at supra-individual level: methods and limitations. In Proc. 13th International Symposium on Veterinary Epidemiology and Economics (ISVEE), Maastricht, the Netherlands, 182

74. Hendrikx P., Gay E., Chazel M., Moutou F., Danan C., Richomme C., Boue F, Souillard R., Gauchard F. \& Dufour B. (2011). - OASIS: an assessment tool of epidemiological surveillance systems in animal health and food safety. Epidemiol. Infect., 139 (10), 1486-1496. 
75. Peyre M., Hendrikx P., Pahm Thi Thanh H., Do Huu D., Goutard F., Desvaux S. \& Roger F. (2011). - Evaluation of surveillance systems in animal health: the need to adapt the tools to the contexts of developing countries, results from a regional workshop in Southeast Asia. Epidémiol. Santé Anim., 59-60, 415-417.

76. Häsler B., Howe K. \& Stärk K. (2011). - Conceptualising the technical relationship of animal disease surveillance to intervention and mitigation as a basis for economic analysis. BMC Hlth Serv. Res., 11 (1), 225. doi:10.1186/1472-6963-11225.

77. Rich K.M., Denwood M.J., Stott A.W., Mellor D.J., Reid S.W.J. \& Gunn G.J. (2013). - Systems approaches to animal disease surveillance and resource allocation: methodological frameworks for behavioral analysis. PLoS ONE, 8 (11), e82019.

78. Peyre M., Zahhaf A., Figuié M., Binnot A., Bonnet P., Goutard F. \& Roger F. (2011). - Socio-economical evaluation of surveillance systems for emerging animal diseases: merging veterinary and public health issues. Ecohealth, 7, S50-S51.

79. Collineau L., Duboz R., Paul M., Peyre M., Goutard F, Holl S. \& Roger F. (2013). - Application of loop analysis for the qualitative assessment of surveillance and control in veterinary epidemiology. Emerg. Themes Epidemiol., 10 (1), 7. doi:10.1186/1742-7622-10-7.

80. Hadorn D.C., Racloz V., Schwermer H. \& Stärk K.D.C. (2009). - Establishing a cost-effective national surveillance system for bluetongue using scenario tree modelling. Vet. Res., 40 (6), 40-57.

81. Haydon D.T., Cleaveland S., Taylor L.H. \& Laurenson M.K. (2002). - Identifying reservoirs of infection: a conceptual and practical challenge. Emerg. Infect. Dis., 8 (12), 1468-1473.

82. Wilson A.J. \& Mellor P.S. (2009). - Bluetongue in Europe: past, present and future. Philos. Trans. Roy. Soc. Lond., B, Biol. Sci., 364 (1530), 2669-2681.

83. Kampen H. \& Werner D. (2010). - Three years of bluetongue disease in central Europe with special reference to Germany: what lessons can be learned? Wien. Klin. Wochenschr., 122 (Suppl. 3), 31-39.

84. Purse B.V., McCormick B.J.J., Mellor P.S., Baylis M., Boorman J.P.T., Borras D., Burgu I., Capela R., Caracappa S., Collantes F., de Liberato C., Delgado J.A., Denison E., Georgiev G., El Harak M., de La Rocque S., Lhor Y., Lucientes J., Mangana O., Miranda M.A., Nedelchev N., Nomikou K., Ozkul A., Patakakis M., Peña I., Scaramozzino P., Torina A. \& Rogers D.J. (2007). Incriminating bluetongue virus vectors with climate envelope models. J. Appl. Ecol., 44 (6), 1231-1242. doi:10.1111/j. 1365-2664.2007.01342.x.
85. Koenraadt C., Balenghien T., Carpenter S., Ducheyne E., Elbers A., Fife M., Garros C., Ibanez-Justicia A., Kampen H., Kormelink R., Losson B., van der Poel W., De Regge N., van Rijn P., Sanders C., Schaffner F, Sloet van Oldruitenborgh-Oosterbaan M., Takken W., Werner D. \& Seelig F. (2014). - Bluetongue, Schmallenberg - what is next? Culicoides-borne viral diseases in the 21st Century. BMC Vet. Res., 10 (1), 77.

86. Tran A., Ippoliti C., Balenghien T., Conte A., Gely M., Calistri P., Goffredo M., Baldet T. \& Chevalier V. (2013). - A geographical information system-based multicriteria evaluation to map areas at risk for Rift Valley fever vector-borne transmission in Italy. Transbound. Emerg. Dis., 60 (Suppl. 2), 14-23. doi:10.1111/ tbed. 12156.

87. EDENext (2014). - Biology and control of vector-borne infections in Europe. Available at: www.edenext.eu/ (accessed on 19 September 2014).

88. Witt C.J., Richards A.L., Masuoka P.M., Foley D.H., Buczak A.L., Musila L.A., Richardson J.H., Colacicco-Mayhugh M.G., Rueda L.M., Klein T.A., Anyamba A., Small J., Pavlin J.A., Fukuda M.M., Gaydos J. \& Russell K.L. (2011). - The AFHSC-Division of GEIS Operations Predictive Surveillance Program: a multidisciplinary approach for the early detection and response to disease outbreaks. BMC Public Hlth, 11 (Suppl. 2), S10. doi:10.1186/1471-2458-11-S2-S10.

89. Coffey L.L., Page B.L., Greninger A.L., Herring B.L., Russell R.C., Doggett S.L., Haniotis J., Wang C.L., Deng X.T. \& Delwart E.L. (2014). - Enhanced arbovirus surveillance with deep sequencing: identification of novel rhabdoviruses and bunyaviruses in Australian mosquitoes. Virology, 448, 146-158.

90. Bichaud L., de Lamballerie X., Alkan C., Izri A., Gould E.A. \& Charrel R.N. (2014). - Arthropods as a source of new RNA viruses. Microb. Pathog., 77, 136-141. doi:10.1016/j. micpath.2014.09.002.

91. Eisen L., Coleman M., Lozano-Fuentes S., McEachen N., Orlans M. \& Coleman M. (2011). - Multi-disease data management system platform for vector-borne diseases. PLoS Negl. Trop. Dis., 5 (3), el016. 
